\title{
To Be or Not to Be...? Part I: Is Global Climate Change a Future Reality?
}

\author{
Ilia Brondz \\ Norwegian Drug Control and Drug Discovery Institute (NDCDDI), Ski, Norway \\ Email: ilia.brondz@gmail.comad
}

Es wird niemals so viel gelogen wie vor der Wahl, während des Krieges und

nach der Jagd.

Otto Eduard Leopold von Bismarck-Schönhausen.

How to cite this paper: Brondz, I. (2017)

To Be or Not to Be...? Part I: Is Global Climate Change a Future Reality? Voice of the Publisher, 3, 25-33.

https://doi.org/10.4236/vp.2017.33003

Received: August 15, 2017

Accepted: September 22, 2017

Published: September 25, 2017

Copyright $\odot 2017$ by author and Scientific Research Publishing Inc. This work is licensed under the Creative Commons Attribution International License (CC BY 4.0).

http://creativecommons.org/licenses/by/4.0/

\begin{abstract}
In the popular, scientific, and politically directed press, and in all kinds of media, e.g., television debates, fictional films, pseudoscientific programs, and animations for children, global climate change is presented as a future reality as a result of human activity. The contrary perspectives on global climate as a global climate stability or a global climate that is independent of human activity, and global climate dependency on other-than-human (e.g., lunar or solar) activities have not been presented in official press, and have been suppressed in popular and "scientific literature". It is obvious that politicians are not interested in the real state, and their decision has already been done based on other grounds than the reality. A great variety of narrow-minded persons should feel subdued, live safely, and be tranquil in their ignorance even if in future they may be robbed for their money and made to look foolish. Our series of papers, "To be or not to be...?" will discuss actions performed by humans that are harmful to the environment and to the global climate, global climate fluctuations that do not depend on human activity, or depend on causes that are beyond human activity.
\end{abstract}

\section{Keywords}

Global Climate Change, Human Activity, Future Reality, Environment, Solar Activity, Supermoon, Earthquakes and Volcanic Eruptions, Fire Farming, Dioxins

\section{Introduction}

The epigraph to this paper was not chosen by chance. The partisan presentation 
of global climate change by media is clear and based on subsidies and grants to scientists and editors, such as those described in [1] [2] [3]. Despite this, even the stoutest narrow-minded person preserved the information about glaciation periods on the Earth at the back of his or her mind. Continuously repeating glaciation periods of icing followed by periods of warming with significant consequences for flora and fauna (including the primates). Continuously repeating glaciation periods of icing and followed periods of warming existed on Earth even before the appearance of Homo sapiens. The spread of the malaria vector and consequently the malaria parasite from Africa to Asia and Europe occurred because of a warming period at the end of the Würm glaciation 6000 years ago, [4]. Somewhat earlier, Homo neanderthalensis became extinct (about 30,000 years ago) because of the deglaciation of Europe and invasion of the Cro-Magnon man (usually named as early humans) who possibly brought with them new infectious diseases or simply cannibalized the $H$. neanderthalensis population as easy prey [5]. "Neanderthal populations ( $H$. neanderthalensis) in Europe endured many environmental changes, including large shifts in climate between glacial and interglacial conditions, while living in a habitat that was colder overall than settings where most other hominin species lived. Some of the environmental shifts they endured involved rapid swings between cold and warm climate... [6] H. sapiens during his existence always was exposed to climatic stress" [6]. Climatic stress was a major factor driving the progress of human intelligence. "Despite many climatic fluctuations, modern humans were able to expand their range over Europe and Asia, and into new areas such as Australia and the Americas" [6]. "Since the beginning of time the world's climate has been subject to change. Periods of intense heat followed by periods of intense cold that have had a profound effect on the lives and development of the planet's flora, and fauna" [7].

From Figure 1, it is obvious that a temperature fluctuation was registered in Europe and on a global scale every 100,000 years. As mentioned in [8], during this time the global temperatures never rose above the critical level to destroy the protein or genetic molecules. It appears that only powerful events can trigger dramatic temperature fluctuations worldwide, e.g., volcanic eruptions [9] or collision with bolides. The lunar influence on the Earth is one of the possible causes of climate changes and is more probable than human activities.

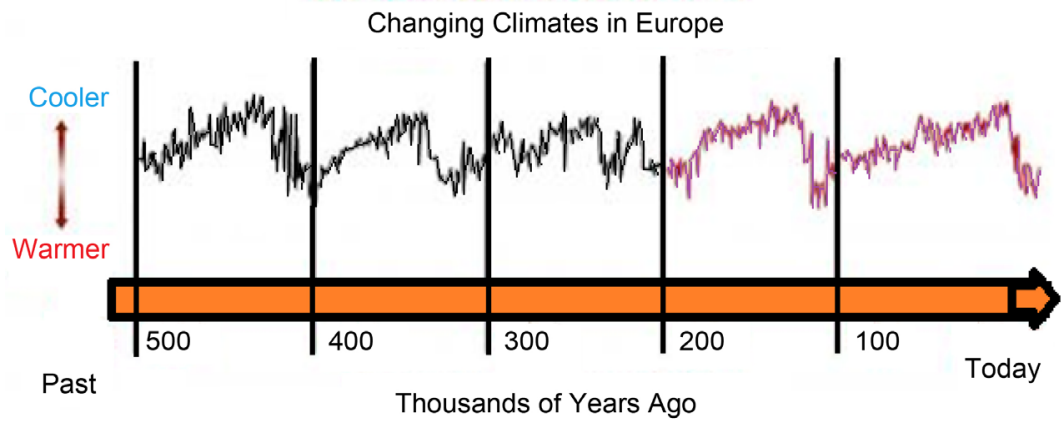

Figure 1. Climate changes in Europe in the last 500,000 years (redrawn from [6]). 


\subsection{Can a Supermoon Cause Climate Changes by Initiating Earthquakes and Volcanic Eruptions?}

A "supermoon" is an astrological and popular term for the full moon at perigee when it is at its closest approach to the Earth (approximately 220,000 miles). Sometimes the Sun, Earth, and Moon or the Earth, Moon, and Sun are aligned. At the time of lunar perigee, the gravitational effect of the Moon on Earth is quite strong; it is especially strong when the Earth, Moon, and Sun are aligned and the Moon and the Sun are on the same side of the Earth. The gravitational attraction of the Moon and Sun in this case can trigger earthquakes, volcanic eruptions, tsunami, and other natural disasters. In recent history, several major disasters were connected to the supermoon occurred. For example, the Turkmenistan earthquake on October 6, 1948, the Mount Pinatubo volcanic eruption, and earthquake and tsunami in Japan the March 11, 2011. On March 19, 2011, the distance between the Earth and the Moon was the closest in the past 18 years. The Moon was just 356,577 kilometers away from the Earth.

“At least two major quakes may support Berkland's theory. The earthquake December 26, 2004, magnitude 9.1 in Sumatra, Indonesia, occurred on the day of a full moon. Likewise, the earthquake March 27, 1964, magnitude 9.2 earthquake in Alaska occurred on the day of maximum high tide" [10]. These events are possibly connected to "syzygy," i.e., the three celestial objects, the Earth, Moon, and Sun were in alignment. It is groundless to believe that all disasters will happen only during one day when the Earth, Moon, and Sun are in alignment. Similar disasters can also happen several days, weeks, or month before and after the celestial alignment.

December 2016 was a supermoon period, which was predated and followed by a number of significant earthquakes in 2016: e.g., in India, west of Imphal in the state of Manipur, on January 3, magnitude 6.7; in Indonesia, east of the Talaud, on January 11, magnitude 6.5; in Japan, southeast of Shizunai, on January 14, magnitude 6.7; in the USA, east of Old Iliamna, Alaska, on January 24, magnitude 7.1; in Indonesia, southwest of MuaraSiberut, Mentawai Islands, on March 2, magnitude 7.8; in Ecuador, south-southeast of Muisne, Esmeraldas province, on April 16, magnitude 7.8; another in Ecuador, northwest of Rosa Zarate in Esmeraldas province on May 18, magnitude 6.9; in Indonesia west of Sungai Penuh, Jambi on June 1, magnitude 6.6; in the United States trust territory of the Northern Mariana Islands, southwest of Agrihan on July 29, magnitude 7.7; in South Georgia and the South Sandwich Islands east southeast of South Georgia on August 19, magnitude 7.4; in New Zealand northeast of Gisborne on September 1, magnitude 7.0; in Papua New Guinea west northwest of Kandrian, West New Britain on October 17, magnitude 6.8; in New Zealand north northeast of Amberley on November 13, magnitude 7.8; in Papua New Guinea east of Taron, New Ireland on December 17, magnitude 7.9.

Significant earthquakes also followed in 2017: in the Philippines, south of Mindanao on January 10, magnitude 7.3; in Tonga north-northwest of the Miner- 
va Reefs on February 24, magnitude 6.9; in Russia, Kamchatka, north-northeast of Ust-Kamchatsk on March 29, magnitude 6.6; in Chile, west of Valparaiso on April 24, magnitude 6.9; in Vanuatu, northeast of Port-Olry on May 9, magnitude 6.8; in Guatemala, north northeast of San Pablo on June 14, magnitude 6.9; in Russia, east-southeast of Nikol'skoye on July 17, magnitude 7.7; and in Turkey, east northeast of Kos, Greece on July 24, magnitude 6.6.

\subsection{Can Solar Activity Cause Climate Changes?}

Even the narrow-minded person knows that almost all warmth on Earth comes from the Sun, and only a small fraction from the Earth's hot core, which is at about $5960^{\circ} \mathrm{C} \pm 500^{\circ} \mathrm{C}$, and from the explosions of nuclear and hydrogen bombs. Thousands of nuclear and hydrogen bombs were exploded on Earth in the atmosphere, underground, and underwater. Personally, I have no doubt that these explosions had only some small effect on the temperature balance; however, they have had a greater significant influence on tectonic activity (some earthquakes can be attributed to these explosions of nuclear and hydrogen bombs), however, significant effect was inflicted on the population of humans and other living creatures on the Earth, i.e., by the initiation of a broad spectrum of related diseases.

Prognoses about the thermal activity of the Earth's core are mostly transparent, i.e., it is slowly cooling down. Therefore, the Earth will slowly cool down during billions of years to be like the Moon (the Earth also will slowly lose its atmosphere).

Over a long term of billions of years, the prognoses for the Sun are similar to those for other stars of insignificant mass; it will cool down.

However, over the short term of several thousand years, the Sun will alternate between high activity with significant solar winds released into space and rising temperatures in the Sun's protuberances and on the superficiality of the Sun. As a consequence of this, there will be disruptions to electronic devices on the Earth and rising temperatures. There will also be periods of low activity on the Sun, which will result in low temperatures on the Earth and possible glaciation of parts or the total surface of the Earth.

Some "power-holding" communities are in a hurry to bind the global population with obligations to pay higher taxes for "global warming" before the end of 2020s. Why? The answer is simple. The coolest period in our time on Earth is expected to approach during approximately the 2030s. Dr. Theodor Landscheidt from the Schroeter Institute for Research in Cycles of Solar Activity has said: "I do not expect that the effects of man-made greenhouse gases will eliminate the sun's predominance" [11] [12] [13] [14]. Dr. Theodor Landscheidt has presented a paper titled "New Little Ice Age Instead of Global Warming?" which is based on his research data and conclusions [14]. He makes a realistic prediction based on real scientific facts.

On August 5, 2017, the BBC disseminated a statement that said the present era 
has been the warmest in Europe for the last 40 years. They apparently have not understood that by making this statement that they by this also testified that there was a period of higher temperatures more than 40 years ago, when the level of $\mathrm{CO}_{2}$ was not as high as today. Why were the temperatures 40 years ago, higher than today? Forty years ago, the global society was not yet exposed to the vigorous and false ideas about the necessity to stifle the developed countries' industries with a duty to pay $\mathrm{CO}_{2}$ taxes.

On the same day, "prominent scientists from the EU committee" used the BBC as a loudspeaker announced that up to 150,000 people will die in Europe per year to the end of the $21^{\text {st }}$ century from high temperature. I would like to propose a different scenario: “... by the end of $21^{\text {st }}$ century, Europe will be inhabited by a high temperature-resistant population from Syria, Iraq, Turkey, Pakistan and Eritrea, and no temperature harm will be observed in this population."

Solar activity can be partially predicted using the Gleissberg cycle and the Sun's oscillatory motion around the center of mass of the solar system. If this should be considered, the coolest period should be expected in the 2030s. The Sun is a major provider of warmth on Earth. A slight drop in the Sun's activity will cause a significant drop in global temperature. This is the reason for the need of authorities to strike the taxation deal for climate change from the global population as soon as possible and obligatory before the 2030s. During ancient times and in the Middle Ages, the "End of the World" was pronounced by the Catholic Church many times for the same purposes, i.e., the taxation of the parish.

\subsection{Smog and Bad Air in Some Megacities as a Lack of Good Ventilation}

It is well-known that periods of bad air and heavy smog happen from time to time in megacities. London was well-known for its smog. London's smog was even immortalized by Joseph Mallord William Turner (April 23, 1775-December 19, 1851), who was an English Romantic landscape painter. Through his paintings, he preserved evidence of the heavy London smog during the $19^{\text {th }}$ century. Today, in $21^{\text {st }}$ century in London, nothing like this is happening despite the incomparable higher level of exhaust gases (including $\mathrm{CO}_{2}$ ) from transport and industry. It is difficult to compare the level of today's exhaust gases and the level of $\mathrm{CO}_{2}$ produced by transport and industry in London with exhaust gases which were produced in the $19^{\text {th }}$ century. What is the reason?

The first reason is the geographic location and characteristics of many cities such as London. These cities were situated where Roman military camps were originally sited and these locations were mainly chosen from a military perspective, instead of for their good natural ventilation. Beijing, Delhi, Bergen, and many other cities have bad natural ventilation as a result of the lack of or insufficient strength of wind. Wind is a provider of natural ventilation. In the present era, unrestricted use of wind power became very popular by building wind pow- 
er stations. The former French president Valéry Marie René Georges Giscard d'Estaing (born February 2nd, 1926) dislikes the destruction of natural views by the ugly silhouettes of wind power stations. Disturbance of views can be important; however, it should be kept in mind that for every $1 \mathrm{~kW}$ of power received by the user as electricity, about $10 \mathrm{~kW}$ of wind power is taken from the wind. At present, it does not do much harm to wind as a natural ventilator; however, if the development in this direction will progress further in future, it will be necessary to build huge ventilation power-stations to restore the good ventilation in cities.

The second reason for London's smog in the $19^{\text {th }}$ century was the lack of accountability and ignorance of city dwellers. In London, for warming, households burned a massive amount of coal and chimneys were poorly constructed. As soon as these practices were abolished and construction of chimneys was improved, the famous London smog disappeared.

The significant producers of bad sanitation and bad air in Beijing are "Street kitchens" which are using poor-quality cooking oil [15] [16], and which also contribute to the significant pollution and poisonous smog to the city air. The situation in Kuala Lumpur and Delhi will be discussed below.

\subsection{Smog and Bad Air in Some Megacities Because of Criminal Activities}

It is not a secret that many forest fires in Europe were started by arsonists. Forest fires may also be started by a smoldering cigarette carelessly thrown out from a car window, or a tourist fire in fields or forests. Arsonists also have a strong impact on the number of forest fires, which cause a lot of destruction of precious flora, irreversible losses of fauna, economic losses, and sometimes also losses human lives. In addition, these fires generate huge contamination from carbon particles, smoke, other particles, and $\mathrm{CO}_{2}$.

Annually some forest fires are deliberately lit. In Indonesia and in many places in Africa and South America, forest and savanna fires were deliberately started by "criminals"; however, the authorities in these countries turn a blind eye to these activities because they "clean" the space for construction or farming. Forest fires that were started in Indonesia annually were of such dimensions that in Kuala Lumpur, Malaysia, it was difficult to breathe. No international condemnations were heard, even these acts of vandalism occur annually. Millions of tons of $\mathrm{CO}_{2}$, dust, and carbon particles have been freed into the atmosphere, precious flora and fauna were destroyed.

\subsection{The Practice of Burning the Stubble and Debris on the Fields after Harvesting the Crops}

In autumn 2016, Delhi experienced an alarming smog because peasants were burning the stubble and debris in the fields after harvesting their crops. The practice of burning the stubble and debris on the fields after harvesting the crops is also called "fire farming" or "fire-stick farming". The habit of burning old 
grass, stubble, and debris possibly originated from Australian Aborigines or because the ashes of forests burned by new settlers in Europe and America in the subsequently cultivated field gave the best harvest in the first year. This custom persists to the present day in India, many African countries, and in other places. Perhaps it was the correct thing to do as an effective kind of fertilization and removal of insects and parasites in the prefertilizer and prepesticide era.

However, times have changed and the custom of burning the stubble and debris on the fields after harvesting the crops coexists with the use of fertilizers and pesticides. In 2016, Delhi suffered a suffocating smog because of stubble and debris fires on the fields around the city. India is one of the biggest exporters of tobacco and cereals. A broad array of fertilizers and pesticides are used in the cultivation of tobacco and cereals. Burning the stubble and debris on the fields after harvesting the crops implies that residuals of fertilizers and pesticides are also being burned and released into the air. It is difficult in this paper to present the consequences for every chemical that has been affected by fire, but it is possible to look at one class (family) of pesticides that is broadly used in the cultivation of tobacco and cereals. Chlorophenoxy acids and their esters are used for the cultivation of tobacco and cereals. After harvesting, some quantities of fertilizers and pesticides remain in the stubble, debris, and soil. The temperature of the fires burning the stubble and debris on the fields is about $700^{\circ} \mathrm{C}-750^{\circ} \mathrm{C}$. This is the exact temperature needed for the conversion of chlorophenoxy acids to dioxins. Therefore, the smog and soil dust are contaminated with dioxins due to "modern fire farming" and thus contaminate the surrounding air and area. The inhabitants of Delhi, Kuala Lumpur, and many other places are exposed to dioxins by this "modern fire farming" practice. Dioxins are highly hazardous and dangerous long-acting poisons. The remaining soil in the field has been enriched with dioxins from this burning over many successive years. Dioxin has a very stable molecule and is consumed by plants: e.g., tobacco, cereals, and other vegetation. Wild and domestic animals also consume this forage from these fields. Crops have also been enriched in dioxins. By these agricultural products such agricultural products as cereals, tobacco, fruits, milk, meat, eggs, and poultry are also contaminated with dioxins. The soil dust that is spread with the wind from "modern fire farming" fields is also contaminated by dioxins. Nearby and distant villagers and cities inhabitants have been exposed to this dust and are subjected to allergic, inflammatory, and cancerous diseases. Consumption of food contaminated by dioxins presents a high risk for contracting cancer and smoking tobacco contaminated with dioxins is a direct way to contract lung cancer.

Numerous manufacturers of tobacco products have been prosecuted because of the harmfulness of their products. Some cigarette manufacturers had no information that they were supplied with raw product containing dioxins. The smoking of dioxin-contaminated tobacco is more than 100 times more harmful than smoking of clean tobacco. The same is correct for eating dio- 
xin-contaminated food. Dioxins are long-acting and persistent poisons with multiple dangerous health effects for humans and animals. The consumption of food products from places using "modern fire farming" methods should be forbidden and the distribution of such food should be considered a criminal act.

\section{Discussion}

It is impossible to take up all the aspects connected to the misrepresentation of climate change issues and environmental mismanagement on the planet in a short article; however, it is possible to present the case of "climate change" by human activity as a fiction. It is possible to demonstrate that politicians intentionally attempt to mislead the public opinion in the wrong direction from environmental criminality to fables on "climate change". In the second paper, "To be or not to be...? Part II" events that affect the environment and the climate on planet Earth other than $\mathrm{CO}_{2}$ also will be presented. A broad and open discussion on the subject is needed and is welcome. The censorship and suppression of free discussion on environmental criminality should be abolished because such discussion is needed desperately. Developing nations should not be allowed to contaminate our environment on our planet under the cover that in the past, developed nations have contaminated the environment and achieved progress by the "cheap money".

\section{References}

[1] Brondz, I. (2015) Analytical Methods in the Quality Control of Scientific Publications Part V: The Fraud of Pseudoscientists Based on False Measurements and Method Development. International Journal of Analytical Mass Spectrometry and Chromatography, 3, 25-31. https://doi.org/10.4236/ijamsc.2015.32003

[2] Brondz, I. (2014) Analytical Methods in Quality Control of Scientific Publications Part IV: Fraud Ordered by the Pharmaceutical Industry. International Journal of Analytical Mass Spectrometry and Chromatography, 2, 103-112.

http://doi.org/10.4236/ijamsc.2014.24009

[3] Brondz, I. (2014) Analytical Methods in Quality Control of Scientific Publications Part III: Publishers' Ethics and Editors' Complicity. International Journal of Analytical Mass Spectrometry and Chromatography, 2, 77-102. https://doi.org/10.4236/ijamsc.2014.23008

[4] Brondz, I. (2011) Historical Overview of Chromatography and Related Techniques in Analysis of Antimalarial Drug Primaquine. Nova Science Publishers, Inc., New York. Inc., ISSN 978-1-61761-944-1.

[5] Brondz, I. (2016) Super Antibiotics, Part I. Hyperforin. Voice of the Publisher, 2, 19-27. https://doi.org/10.4236/vp.2016.24004

[6] What Does It Mean to Be Human? Climate Effects on Human Evolution, Smithsonian National Museum of Natural History. http://humanorigins.si.edu/research/climate-and-human-evolution/climate-effectshuman-evolution

[7] How Climate Change can affect Human Evolution. http://www.earthtimes.org/climate/how-climate-change-effect-human-evolution/18 49/\#vvUeohYvmfWrf4SU.99 
[8] Brondz, I. (2015) The Journal Voice of the Publisher. Voice of the Publisher, 1, 1-7. https://doi.org/10.4236/vp.2015.11001

[9] Stothers, R.B. (1984) The Great Tambora Eruption in 1815 and Its Aftermath. Science, 224, 1191-1198. https://doi.org/10.1126/science.224.4654.1191

[10] Roach, J. (2005) Can the Moon Cause Earthquakes? National Geographic News, Reporting Your World Daily, May 23, 2005.

http://news.nationalgeographic.com/news/2005/05/0523_050523_moonquake.html

[11] Landscheidt, T. (2000) New Confirmation of Strong Solar Forcing of Climate. http://www.john-daly.com/po.htm

[12] Landscheidt, T. (2001) Solar Eruptions Linked to North Atlantic Oscillation. http://www.john-daly.com/theodor/solarnao.htm

[13] Landscheidt, T. (2001) Trends in Pacific Decadal Oscillation Subjected to Solar Forcing. http://www.john-daly.com/theodor/pdotrend.htm

[14] Landscheidt, T. (2007) New Little Ice Age Instead of Global Warming? http://www.schulphysik.de/klima/landscheidt/iceage.htm

[15] https://en.wikipedia.org/wiki/Gutter_oil

[16] https://www.youtube.com/watch?v=zrv78nG9R04

Submit or recommend next manuscript to SCIRP and we will provide best service for you:

Accepting pre-submission inquiries through Email, Facebook, LinkedIn, Twitter, etc. A wide selection of journals (inclusive of 9 subjects, more than 200 journals)

Providing 24-hour high-quality service

User-friendly online submission system

Fair and swift peer-review system

Efficient typesetting and proofreading procedure

Display of the result of downloads and visits, as well as the number of cited articles

Maximum dissemination of your research work

Submit your manuscript at: http://papersubmission.scirp.org/

Or contact vp@scirp.org 